\title{
Web rotational stiffness of continuous steel-concrete composite castellated beams
}

\author{
Carla Cristiane Silva, Rodrigo Barreto Caldas, Ricardo Hallal Fakury, Hermes Carvalho, João \\ Victor Fragoso Dias \\ Department of Structural Engineering, Federal University of Minas Gerais, Av. Pres. Antônio Carlos, 6627, Pampulha, Belo \\ Horizonte, Minas Gerais 31270-901, Brazil \\ carlacristianesilva@hotmail.com
}

\begin{abstract}
Continuous composite beams can present a global instability known as lateral distortional buckling (LDB). The design code EN 1994-1-1:2004 provides a procedure for the verification of this ultimate limit state, in which the resistant bending moment is calculated considering the behavior of the inverted "U-frame" mechanism. An essential parameter for the determination of this moment is the rotational stiffness of the composite beam, which depends on the web stiffness. The EN 1994-1-1:2004 procedure is restricted to composite beams with solid-web steel sections without openings. This paper presents several numerical analyses of the web rotational stiffness of castellated sections such as Anglosaxon, Litzka and Peiner typologies. Finally, based on numerical results obtained, three different adjustment coefficients were proposed for the Anglo-Saxon, Litzka and Peiner typologies for the calculation of the web rotational stiffness of the castellated profile. The proposed coefficients provided an excellent adjustment between the results obtained numerically and those obtained from the classical formulation of the plate theory, with an average deviation of $2 \%$, indicating low dispersion and homogeneous results.
\end{abstract}

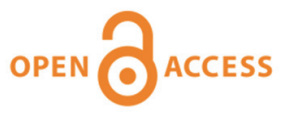

Citation: Silva, C. C., Caldas, R. B., Fakury, R. H., Carvalho, H., Dias, J., V., F., Web rotational stiffness of continuous steelconcrete composite castellated beams, Frattura ed Integrità Strutturale, 50 (2019) 264-275.

Received: 16.06 .2019

Accepted: 16.08 .2019

Published: 01.10.2019

Copyright: (C) 2019 This is an open access article under the terms of the CC-BY 4.0, which permits unrestricted use, distribution, and reproduction in any medium, provided the original author and source are credited.
KEYwORDS. Rotational stiffness; Castellated composite beam; Lateral distortional buckling; Elastic critical moment.

\section{INTRODUCTION}

$\mathrm{I}$ n continuous and semi-continuous composite beams, in the regions of hogging moment, the bottom flange is compressed, which makes it susceptible to buckling in relation to its major axis of inertia (axis located in the plane of flexion), since the buckling in relation to the its minor axis of inertia is restrained by the web. If the web has insufficient stiffness to prevent lateral flexion, the compressed flange shows a lateral displacement, $\delta$, accompanied by a twist, $\theta$, (Fig. 1), characterizing an ultimate limit state called lateral distortional buckling (LDB). 


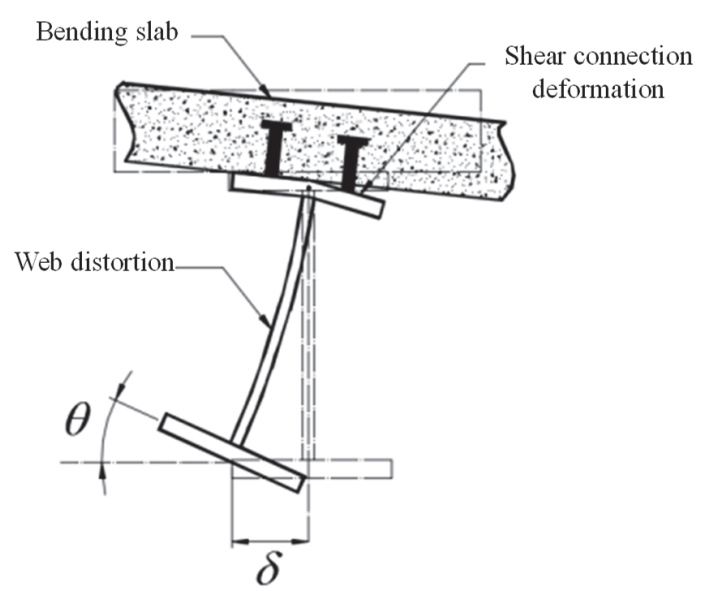

Figure 1: Lateral distortional buckling (Oliveira [1]).

Continuous and semi-continuous composite beams can be used with castellated sections, which are structural elements with multiple hexagonal openings of the same shape, regularly spaced in the web. The main reasons for the use of castellated beams in steel structures are increase of resistant capacity and flexural stiffness around the axis of greater inertia, provided by the increase of the total height of the cross section; elements lighter than a profile without openings of the same height, thus reducing the total weight; larger free spans, reducing the number of columns and foundations, leading to faster and more economical assembly; possibility of passing ducts or pipes through the openings and aesthetic gain, since the openings incorporate to the environment a modern appearance.

Adding the potential of castellated steel beams for use in composite floors, the effect on material economy is even more promising once the steel-concrete composite beams are a very effective floor system due to the considerable increase in floor stiffness, steel weight reduction and the lower height of the beam-slab section (Queiroz et al. [2]).

The Brazilian standard ABNT NBR 8800:2008 [3] provides a procedure for the determination of the lateral distortional buckling-moment resistance capacity of the continuous and semi-continuous steel-concrete composite beams, similar to the EN 1994-1-1:2004 [4] European standard. This procedure depends on the determination of the elastic critical moment, calculated considering the behavior of the inverted " $U$-frame" mechanism. A fundamental parameter for this determination is the rotational stiffness of the composite beam which, in turn, depends on the web stiffness. It should be noted that these code procedures apply only to composite beams without web openings.

In the literature there are several studies on lateral distortional buckling (LDB) of continuous composite beams without web openings, among them Roik et al. [5], Chen [6], Dekker et al. [7], Hanswille et al. [8], Calenzani [9], Calenzani [10], Chen and Wang [11], Ye and Chen [12], Wang [13], Guo et al. [14], Zhou et al. [15], Zhou et al. [16], Oliveira [17], Amaral [18] Dietrich [19], Dias [20] and Oliveira [1].

The number of researches of castellated composite beams in regions of hogging moments is still limited. Salah and Gizejowski [21, 22, 23] performed several studies with alveolar beams (cellular and castellated openings) to analyze the influence of beam slenderness (length to height ratio), distortional buckling modes, profile height and steel type. Piassi et al. [24] developed an analytical model in order to obtain the expression of the rotational stiffness of composite cellular beams and the results were compared with numerical models developed in the ANSYS 15.0 [25] program.

However, there are no studies on the rotational stiffness of the web castellated profile. Therefore, this paper presents a numerical study, validated with results of the literature, with the aim of proposing an equation for the calculation of the bending stiffness of the web of steel-concrete composite beams, which can be used to determine the rotational stiffness of the inverted "U-frame" mechanism and obtain the elastic critical moment of lateral distortional buckling.

\section{LITERATURE REVIEW}

\section{Inverted "U-frame" mechanism}

he European standard EN 1994-1-1:2004 [4] and the Brazilian standard ABNT NBR 8800: 2008 [3] suggest the use of the inverted "U-frame" mechanism to determine the elastic critical moment of LDB, in which the concrete slab is considered to be over two or more parallel steel beams, as shown in Fig. 2. 


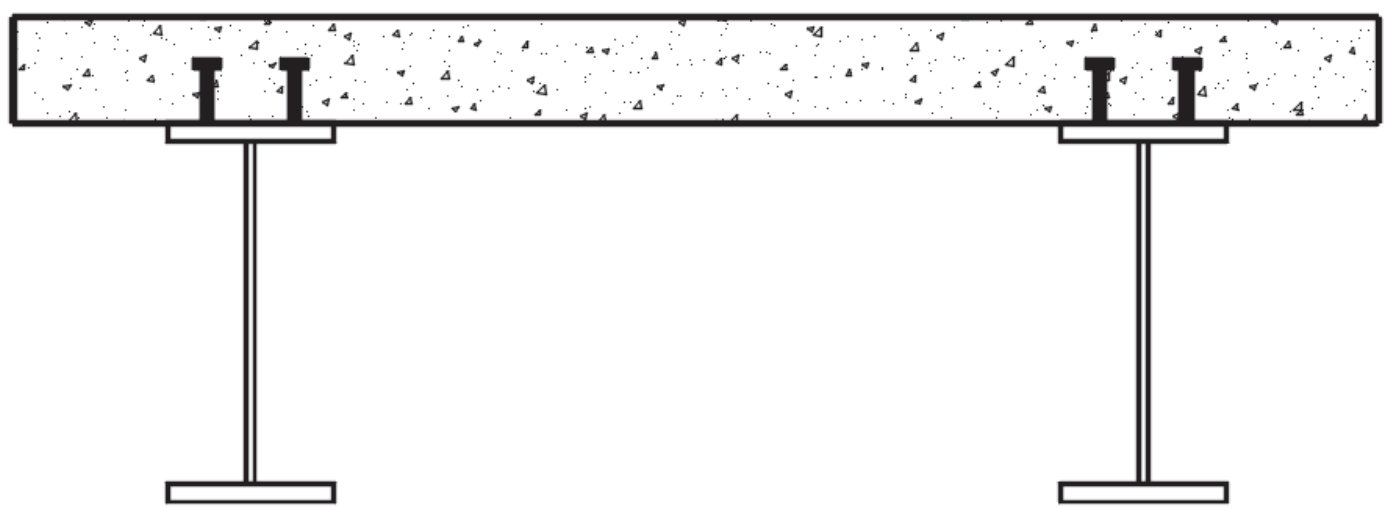

Figure 2: Inverted "U-frame” mechanism with two beams (Oliveira [1]).

According to Fan [26], the inverted "U-frame" mechanism is more adequate to represent the behavior to LDB compared to the model of a composite beam composed of a single steel profile superimposed on a concrete slab ("T" cross section) because it represents better the lateral displacement and torsional constraints imposed on the steel profile by the concrete slab and the shear connection. The "U-frame" mechanism also has a direct relation with the usual situations, once most constructions use floor systems composed of parallel steel beams equally spaced under the concrete slab.

In the literature there are two types of inverted "U" mechanism, the continuous one, which has only rigid internal supports, and the discrete one, which has regularly spaced transversal stiffeners throughout the hogging moment region, which contributes to the restriction of LDB. The EN 1994-1-1:2004 [4] and ABNT NBR 8800:2008 [3] standards only present formulations considering the continuous "U-frame" mechanism for the verification of composite beams.

\section{Rotational Stiffness}

A fundamental parameter for the calculation of the elastic critical moment $\left(M_{c r}\right)$ is the rotational stiffness of the composite beam, $k_{s}$, also known as the rotational stiffness of the inverted "U-frame" mechanism. This stiffness, considered simplified by a rotational spring located in the top flange of a steel profile, allows to reproduce the influence of the "U-frame" mechanism at the bending moment resistant to the LDB, considering the bending of the slab, the distortion of the web and the deformation of the shear connection (Fig. 3). According to Johnson [27], this stiffness is obtained by unit of length, relating the moment at point $\mathrm{A}$, located in the geometric center of the top flange, caused by forces, $F$, applied to the bottom flanges of the parallel beams of the "U-frame" mechanism, with the corresponding rotation, $\theta$, of these flanges. This rotation is obtained by the ratio between the lateral displacement of the bottom flange $(\delta)$ and the distance between the geometric centers of the flanges of the steel profile $\left(b_{0}\right)$. The bending moment at point $\mathrm{A}$ is the product between force $F$ and distance $h_{0}$. Taking one of the beams, the rotation at point $\mathrm{A}$ will be equal to $\delta / h_{0}$, and since the moment in $\mathrm{A}$ is given by the product $F . h_{0}$, the following general expression for the rotational stiffness is obtained:

$$
k_{s}=\frac{F h_{o}}{\delta / h_{o}}
$$

To determine precisely Eqn. (1), it is necessary to carry out experimental or numerical analyses. Alternatively, the rotational stiffness of the composite beam $\left(k_{s}\right)$ can be obtained as a result of the series association of the cracked slab bending stiffness, $k_{1}$, the steel profile web rotational stiffness, $k_{2}$, and shear connection bending stiffness, $k_{3}$, as follows:

$$
k_{s}=\left(\frac{1}{k_{1}}+\frac{1}{k_{2}}+\frac{1}{k_{3}}\right)^{-1}
$$

For the calculation of the slab bending stiffness, $k_{1}$, the slab is considered as a beam fixed on the profiles. This stiffness is characterized by the bending moments that arise when applying unitary rotations on the fixed ends (Fig. 4) and, generally, can be obtained as: 


$$
k_{1}=\frac{\alpha(E I)_{2}}{a}
$$

where $a$ is the distance between the parallel beams of the inverted "U-frame" mechanism, $\alpha$ is a coefficient depending on the position of the beam being considered. If the beam is at the end of the slab, $\alpha=2$, and for the internal beam, $\alpha=3$ (for internal beams with four or more similar beams, one can adopt $\alpha=4$ ). The term $(\mathrm{EI})_{2}$ represents the bending stiffness of the homogenized composite section of the slab, disregarding the tensile concrete, per unit length of the beam, taken as the lowest value between the stiffness in the middle of the span and in the internal support.

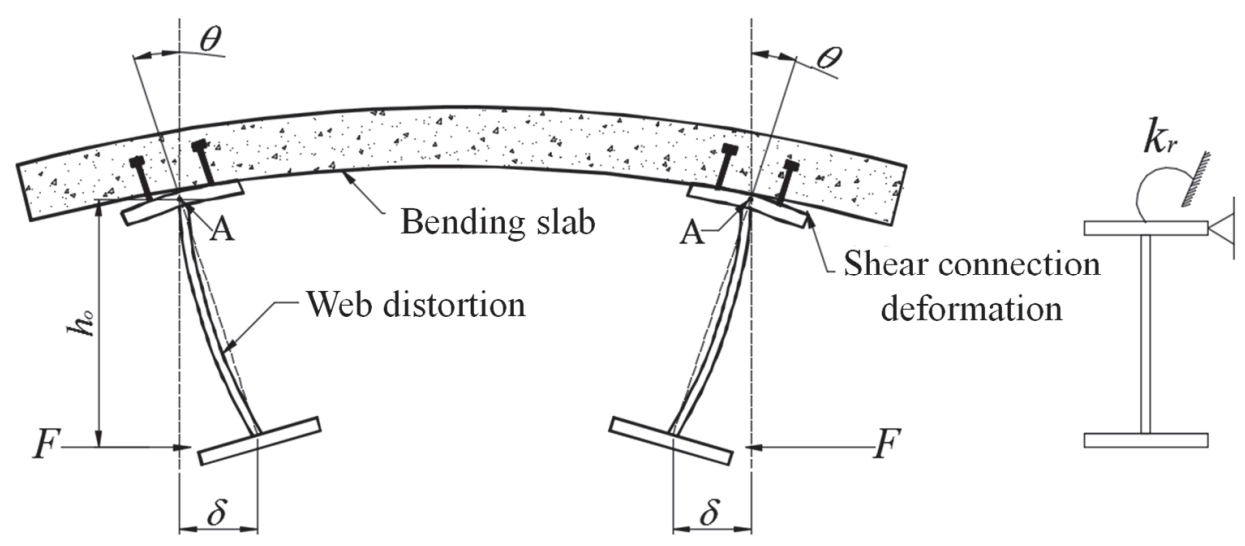

Figure 3. Rotational stiffness of a composite beam (Oliveira [1]).

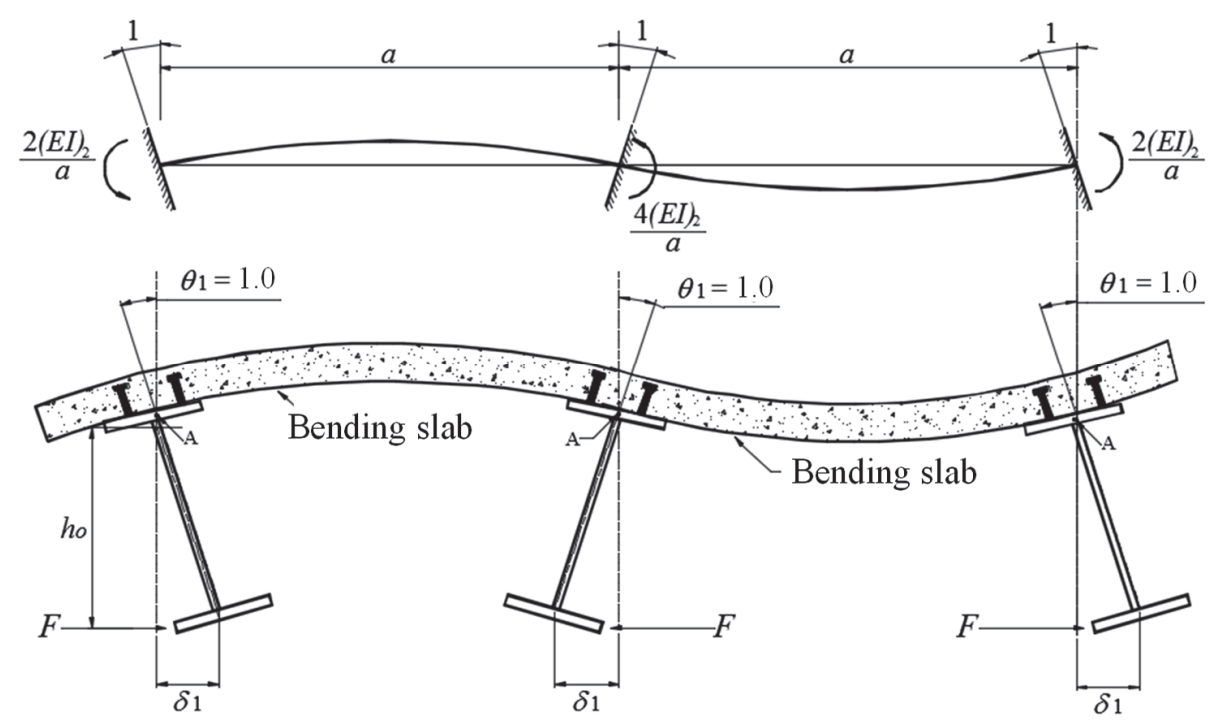

Figure 4. Cracked slab bending stiffness (Calenzani [9]).

The steel profile web rotational stiffness is obtained by considering the web as a cantilever plate in the geometric center of the top flange and free in the geometric center of the bottom flange where a force $F$ acts, according to Fig. 5.

The relation between the force $F$ and the displacement $\delta_{2}$ is given by the expression:

$$
\frac{F}{\delta_{2}}=\frac{3 D}{h_{0}^{3}}
$$


where $D$ is the plate bending stiffness per unit length.

According to Eqn. (1) and rearrangement of Eqn. (4), we obtain:

$$
k_{2}=\frac{3 D}{h_{0}}
$$

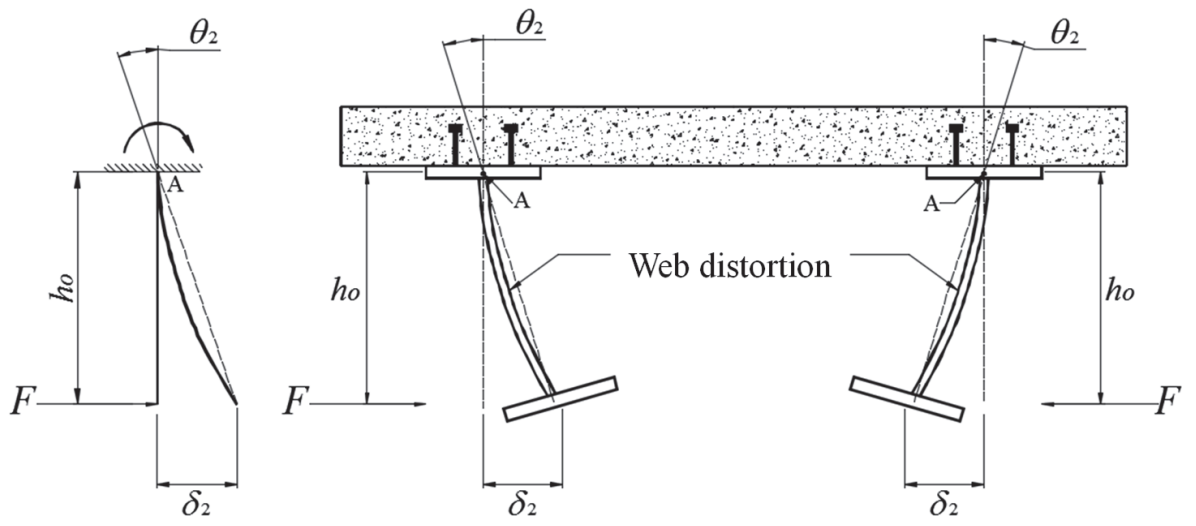

Figure 5. Web rotational stiffness (Calenzani [9]).

The plate bending stiffness per unit length can be calculated, according to Timoshenko and Gere [28], as:

$$
D=\frac{E t_{w}^{3}}{12\left(1-v^{2}\right)}
$$

where $E$ and $\nu$ are, respectively, the Young's modulus and the Poisson's ratio of the structural steel and $t_{w}$ is the web thickness of the steel profile. Substituting Eqn. (6) for Eqn. (5), the value of $k_{2}$ per unit length can be determined by:

$$
k_{2}=\frac{E t_{w}^{3}}{4 h_{o}\left(1-v^{2}\right)}
$$

The web rotational stiffness, $k_{2}$, determined for the plate without openings, described in Eqn. (7), should be adapted in the case of alveolar beams for the consideration of the openings, and being this adaptation the proposal of this article.

The shear connection bending stiffness $\left(k_{3}\right)$ represents the moment in the geometric center of the top flange when a unitary rotation is imposed for the connection between the steel profile and the reinforced concrete slab (Fig. 6). The analytical determination of this stiffness is very difficult. According to Johnson and Molenstra [29] apud Calenzani [9], it tends to have a very high value when the I section has no openings, influencing less than $1 \%$ of the rotational stiffness $k_{s}$ for the case of shear connection with two connectors in the cross section and less than $5 \%$ for one shear connector. For this reason, the stiffness $k_{3}$ is usually disregarded in the calculations. In the case of castellated beam, in which the presence of openings reduces the web stiffness, the influence of the shear connection becomes even less relevant.

The European standard EN 1994-1-1:2004 [4] does not provide an equation for the calculation of the elastic critical moment of LDB, but suggests the use of the inverted "U-frame" mechanism. The elastic critical moment of LDB is obtained, according to Brazilian standard ABNT NBR 8800:2008 [3], by Eqn. (8) (which was also presented in the previous version of the European standard, ENV 1994-1-1:1992 [29]), initially proposed in the Roik et al. [5] studies:

$$
M_{c r}=\frac{C_{d i s t} \alpha_{g}}{L} \sqrt{G J+k_{s} \frac{L^{2}}{\pi^{2}} E I_{a f j}}
$$

in which $G$ is the transverse elasticity modulus, $E$ is the Young's modulus of the structural steel, $J$ is the St. Venant torsion constant of the profile, $I_{a f}$ is the second moment of area of the compressed flange in relation to the $y$ axis (vertical axis), $\alpha_{g}$ 
is a related factor to the cross-section geometry, $k_{s}$ is the rotational stiffness of the composite beam and $C_{\text {dist }}$ is a coefficient that depends on the distribution of bending moments in the length $L$ of the analyzed composite beam span.

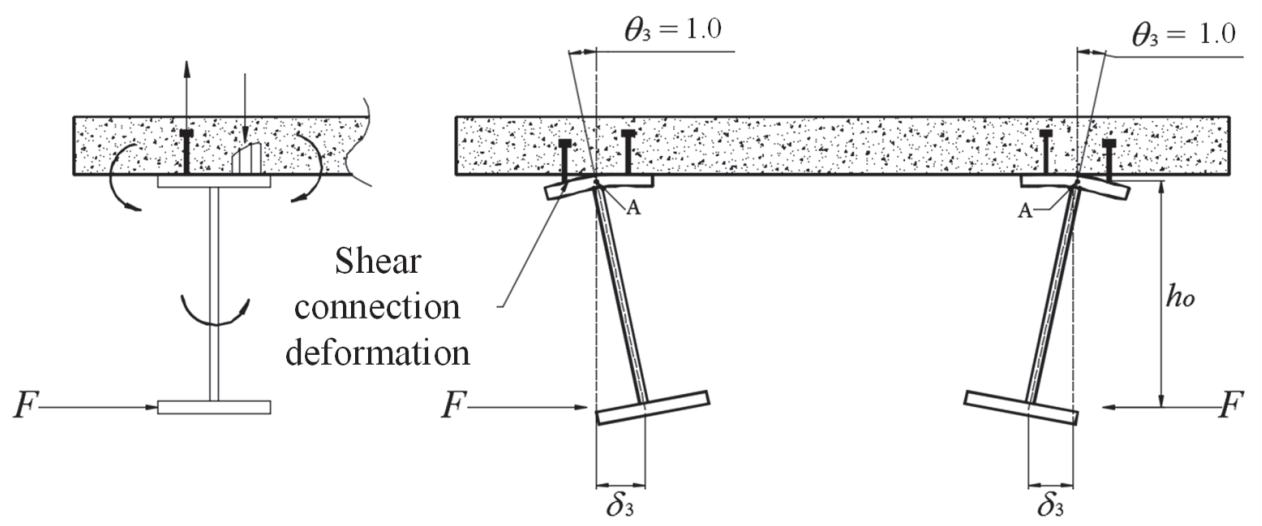

Figure 6. Shear connection bending stiffness (Calenzani [9]).

Dias [20] proposed a new procedure for the determination of the elastic critical moment of composite beams with web profile without openings subjected to uniform hogging moment according to Eq. (10):

$$
M_{c r}=\frac{k_{g}}{h_{0}}\left\{G J+\frac{E C_{w, d}}{L^{2}}\left[(n \pi)^{2}+\left(\frac{\eta_{b}}{n \pi}\right)^{2}\right]\right\}
$$

where

$$
\eta_{b}=\sqrt{\frac{k L^{4}}{E C_{w, d}}}
$$

where $h_{0}$ is the distance between the geometric centres of the steel profile flanges, $G$ the transverse elasticity modulus, $E$ the Young's modulus of the structural steel, $J$ the St. Venant torsion constant of the steel profile, $L$ the beam length, $C_{m, d}$ the warping constant of the steel profile, $n$ the number of half-waves of the buckling mode, $k$ the spring stiffness in the centre of the upper face of the top flange, $\eta_{\mathrm{b}}$ is a dimensionless parameter and $k_{g}$ takes into account effects caused by the presence of the slab in the model.

The new procedure proposed by Dias [20] presented excellent agreement with numerical values, with deviations below $10 \%$ in $97.29 \%$ of the analyzed models and mean error of $2.33 \%$. Results better than the formulations of Roik et al. [5] and Hanswille et al. [8], which did not lead to satisfactory results, presenting average errors of $12.41 \%$ and $16.51 \%$, respectively. These last two works present several simplifications and can lead to results not as precise as those of Dias [20].

Oliveira [1] extended the equation of Dias [20] for composite beams submitted to non-uniform hogging moment.

\section{NUMERICAL ANALYSIS}

\section{Numerical Model}

7 he formulation of the rotational stiffness discussed in EN 1994-1-1:2004 [4] covers only composite beams composed of steel profiles without openings. This stiffness depends substantially on the web rotational stiffness $\left(k_{2}\right)$, which can be determined by considering the web as a plate fixed in the geometric center of the top flange and free in the geometric center of the bottom flange (Fig. 7). Thus, a simplified numerical model of plate was developed to determine the web stiffness of the castellated profiles.

The numerical model represents a plate of height $\left(d_{g}\right)$, thickness $t_{w}$ and length varying due to the number of openings, in the case of the castellated web (Fig. 5). As described previously, by applying a horizontal force $F$ in the geometric center 
of the bottom flange, the web lateral displacement $\left(\delta_{2}\right)$ can be determined through Eqn. (1) and, from this, the web stiffness, $k_{2}$, is calculated.

Three-dimensional models of finite elements were developed in the software ANSYS 17.0 [25]. Shell elements, SHELL181, were used to represent the steel profile.

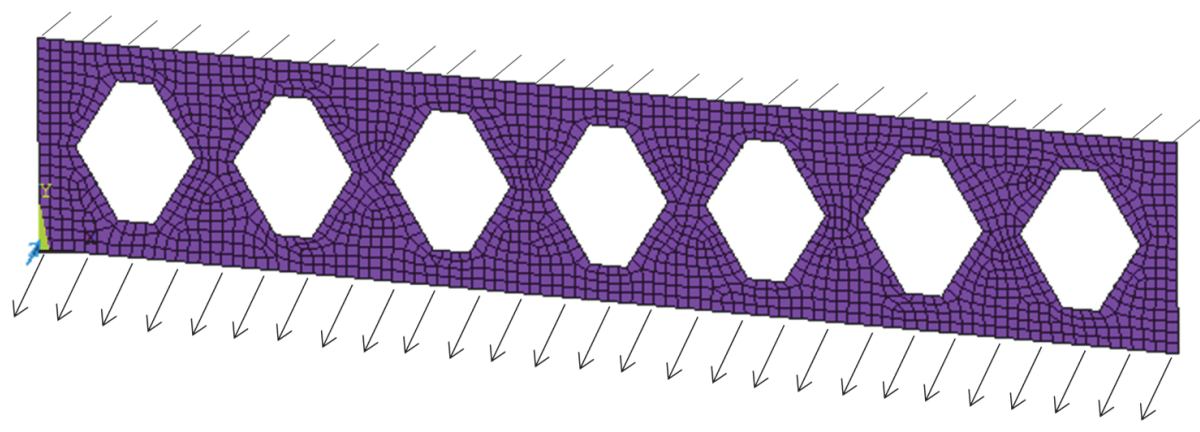

Figure 7. Plate model.

The Young's modulus of the steel, E, was considered equal to $200000 \mathrm{MPa}$ and the Poisson's ratio, $\nu$, equal to 0.3. In order to simulate the boundary conditions, the displacements and rotations in the three directions were prevented at the top of the web. At the bottom, the nodes displacements were coupled, resulting in a uniform displacement along the lower portion of the web across the model length, condition which normally occurs due to the presence of the bottom flange.

The finite element mesh was generated freely by the program, resulting in an unstructured mesh, which does not represent influence due to the great simplicity of the type of analysis. A mesh study was performed, varying the size of the elements from large values to very small values $\left(1.52 h_{0}\right.$ to $0.003 h_{0}$, with more than 32 values). The mesh used was $0.152 h_{0}$ once it presented results with good precision (the variation for smaller meshes is less than $0.1 \%$ ) and did not present high computational time.

\section{$V$ alidation of Numerical Model}

Plates with solid-webs were modeled for the validation of the numerical model. The numerical web rotational stiffness without openings $\left(k_{2, \text { num }, 50 l}\right)$ was calculated according to Eqn. (1), considering the applied force $(F)$ equal to $1 \mathrm{kN}$ and the maximum displacement of the plate $\left(\delta_{2}\right)$ obtained from the numerical analysis. The analytical web rotational stiffness without openings $\left(k_{2, a n, s o l}\right)$ was calculated according to Eqn. (7). The results of the numerical analysis were compared with the analytical results and it was observed that the maximum difference between the two results was less than $0.3 \%$ (Tab. 1). Therefore, it is considered that the numerical model is suitable for simulations of web stiffness.

\begin{tabular}{|c|c|c|c|c|c|c|}
\hline$d_{g}(\mathrm{~mm})$ & $t_{w}(\mathrm{~mm})$ & $L_{\text {beam }}(\mathrm{m})$ & $\begin{array}{l}\delta_{2} \\
(\mathrm{~m})\end{array}$ & $\begin{array}{c}k_{2, \text {, num } 1,50 l} \\
(\mathrm{kN} \cdot \mathrm{m} / \mathrm{m})\end{array}$ & $\begin{array}{c}k_{2, a l u, s o l} \\
(\mathrm{kN} \cdot \mathrm{m} / \mathrm{m})\end{array}$ & $k_{2, \text { num }}$, sol $/ k_{2, a l, s o l}$ \\
\hline 260 & 6.4 & 2.85 & $4.28 \mathrm{E}-04$ & 55393.01 & 55398.14 & 1.000 \\
\hline 300 & 5.0 & 1.99 & $1.98 \mathrm{E}-03$ & 22893.71 & 22818.77 & 0.997 \\
\hline 600 & 7.5 & 4.85 & $1.93 \mathrm{E}-03$ & 38543.48 & 38633.24 & 0.998 \\
\hline 900 & 10 & 11.17 & $1.19 \mathrm{E}-03$ & 61113.43 & 61050.06 & 1.001 \\
\hline 1200 & 15 & 14.89 & $6.25 \mathrm{E}-04$ & 154755.51 & 154532.97 & 1.001 \\
\hline
\end{tabular}

Table 1: Validation of numerical models. 


\section{PARAMETRIC STUdy}

7 he plates evaluated in this study had Anglo-Saxon, Peiner and Litzka typologies (Tab. 2 shows the geometric ratios for the castellated beam typology patterns and Fig. 8 illustrates their parameters) with an expansion ratio equal to 1.5. This value is usual for the alveolar profile, used by several authors in their experimental and numerical works (Zaarour and Redwood [30]; Bezerra [31]; Vieira [32]).

\begin{tabular}{cccc}
\hline & Anglo-Saxon & Litzka & Peiner \\
$p$ & $1.08 d$ & $1.7322 d$ & $1.5 d$ \\
$b_{w}$ & $0.25 d$ & $0.5774 d$ & $0.5 d$ \\
$a_{0}$ & $0.83 d$ & $1.155 d$ & $d$ \\
$b$ & $0.29 d$ & $b_{w} / 2$ & $b_{w} / 2$ \\
\hline
\end{tabular}

Table 2: Geometric parameters for the beams.

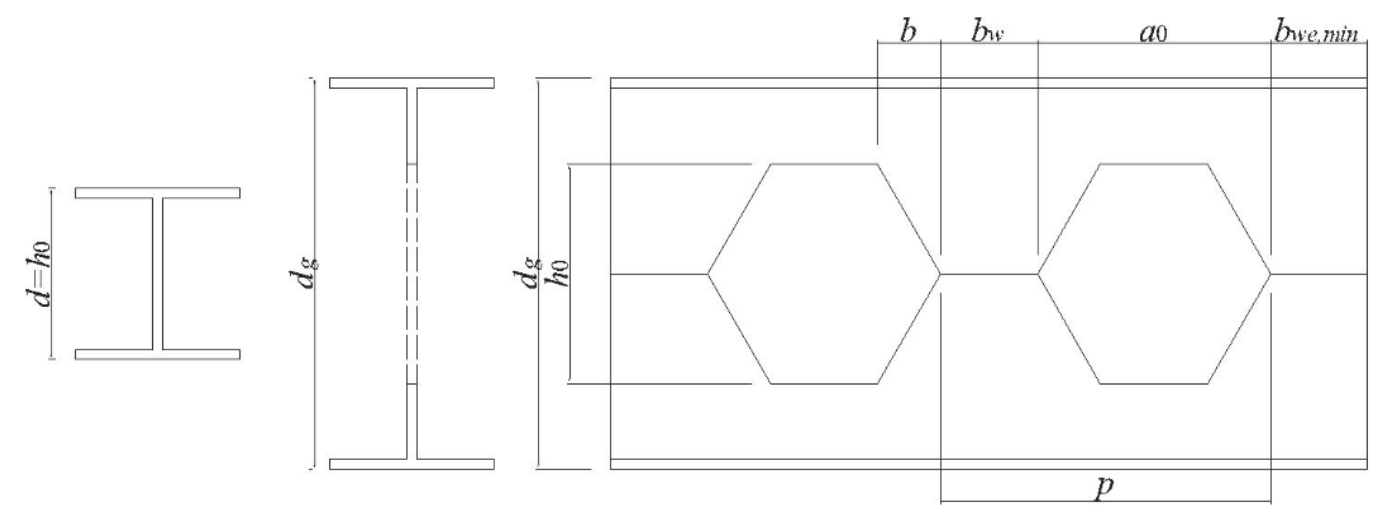

Figure 8. Definition of geometric parameters for the beams.

The parametric study was performed considering four heights, $d_{g}, 300,600,900$ and $1200 \mathrm{~mm}$, covering large and small heights. In relation to the thickness of the castellated web, the web slenderness values $\left(d_{g} / t_{w}\right)$ equal to $20,40,60$ and 80 were analyzed, covering larger and smaller slenderness than usual slenderness values. The profiles were modeled with a number of openings, $n$, equal to $5,7,9,11,13,15,17,19$ and 21 , in order to verify if the increase of the span would influence the stiffness. A total of 432 models were analyzed, with the combinations of properties presented in Fig. 9.

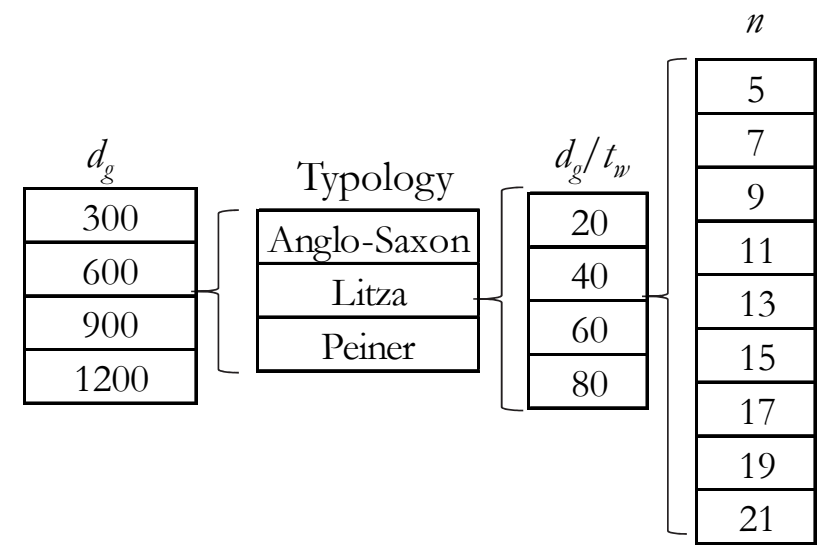

Figure 9. Models analyzed in the web rotational stiffness parametric study. 


\section{RESULTS AND DisCUSSION}

$\mathrm{F}$ ig. 10 shows the relationship between the results of the numerical analyses of plates with hexagonal openings and the values obtained according to the analytical formulations of web plates without openings (considering the same dimensions) for Anglo-Saxon, Litzka and Peiner typologies. The numeric stiffness of the castellated web, $k_{2, \text { num }}$, cast was calculated according to Eqn. (1) and the analytic stiffness of the web without openings, $k_{2, a n, s o l}$, calculated by Eqn. (7). A linear relationship between the results of $k_{2, \text { num }}$, cast and $k_{2, \text { an, sol }}$ is shown for the three typology patterns studied, with the mean of the ratio $k_{2, \text { numm,ast }} / k_{2, \text { an, sol }}$ equal $0.53,0.54$ and 0.55 for the Anglo-Saxon, Litzka and Peiner typologies, respectively.

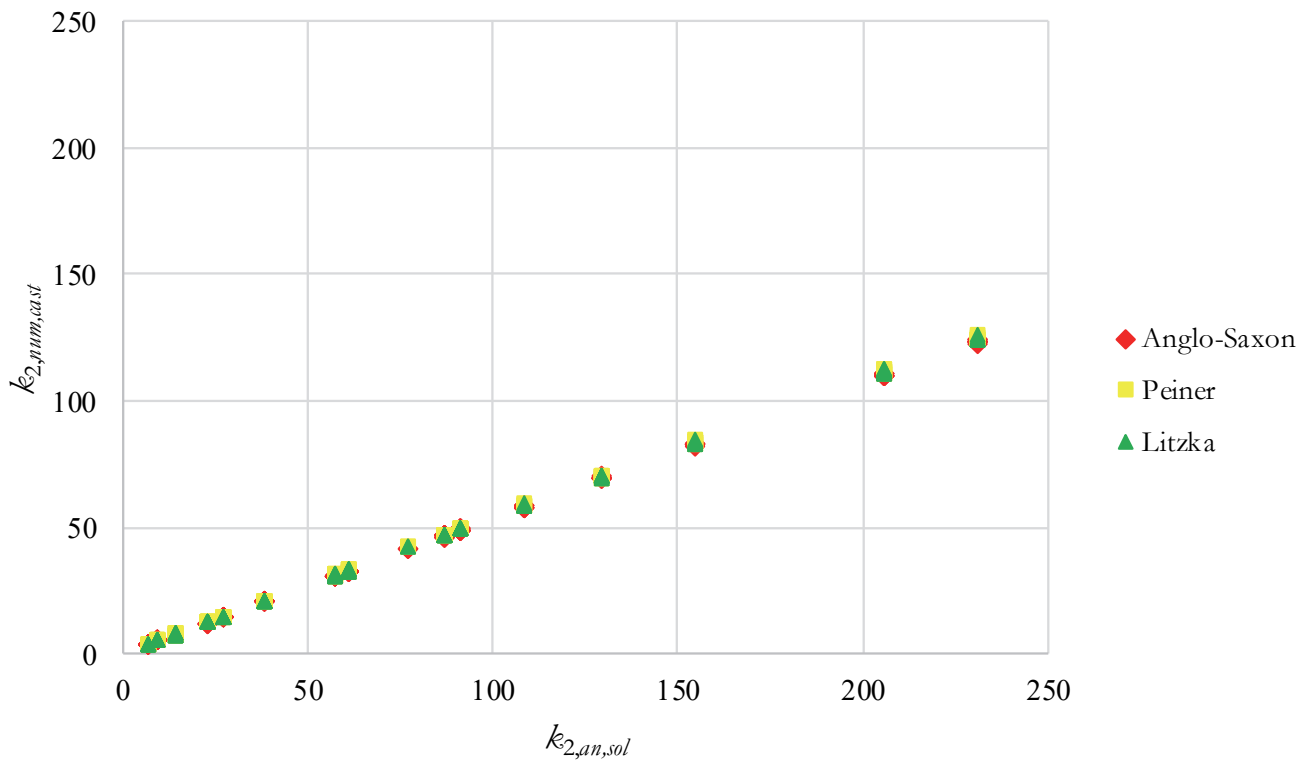

Figure 10. Comparison between the numerical and analytical results of the web stiffness of the Anglo-Saxon, Litzka and Peiner typologies.

Adopting an adjustment coefficient ( $\beta$ ), the Eqn. (7), used by EN 1994-1-1:2004 [4] and ABNT NBR 8800:2008 [3], can be adapted for the determination of the rotational stiffness of castellated webs, considering the total height of the castellated beam, $d_{g}$, instead of the height of web without openings, $h_{0}$, as below:

$$
k_{2}=\beta \frac{E t_{w}^{3}}{4 d_{g}\left(1-v^{2}\right)}
$$

in which $\beta$ is:

$$
\beta=\left\{\begin{array}{cc}
0.53 & \text { Anglo-Saxon } \\
0.54 & \text { Liztka } \\
0.55 & \text { Peiner }
\end{array}\right.
$$

A dispersion analysis of the results was performed as described in the European standard EN 1990:2002 [33], and the coefficient of variation for the proposed formulation was equal to $0.22 \%$, indicating low dispersion and homogeneous results. Adopting, conservatively, a simplified adjustment coefficient, $\beta_{\text {simplifed, }}$, equal to 0.53 for Eqn. (11), can determine only one equation for the stiffness of the castellated beams (Anglo-Saxon, Peiner and Litzka typologies), in which the error obtained is less than $4 \%$. It was also observed that the number of openings had no great influence on the rotational stiffness of the castellated web. 


\section{CONCLUSION}

$\mathrm{T}$ he union between the potential of the continuous composite beams and the castellated steel profiles is promising for material savings. Despite this, the construction of these beams runs into deficiency of studies about their behavior. In the case of continuous composite beams, the ultimate limit state of lateral distortional buckling deserves special attention.

This ultimate limit state depends fundamentally on the web rotational stiffness. In castellated sections the openings in the web of the composite beams reduce the web rotational stiffness of these profiles when compared to those without openings, which makes these beams more susceptible to this buckling mode. According to the standards EN 1994-11:2004 [4] and ABNT NBR 8800:2008, in order to obtain the lateral distortional buckling resistant moment, it is necessary to calculate the elastic critical moment which depends on the geometric properties of the steel profile and the rotational stiffness of the composite beam.

In this paper, three different adjustment coefficients $(\beta)$ were proposed for the Anglo-Saxon, Litzka and Peiner typologies of castellated beams, $0.53, .054$ and 0.55 , respectively, for the calculation of the web rotational stiffness of the castellated sections, fundamental variable for obtaining the rotational stiffness of the composite beam and, consequently, the elastic critical moment of lateral distortional buckling. As the web rotational stiffness is reduced, the elastic critical moment will also be smaller and, consequently, the resistant moment. The coefficients were obtained (one for each of the opening patterns) from a parametric numerical study performed in the software ANSYS 17.0 [25].

The proposed coefficients provided an excellent adjustment between the results obtained numerically and those obtained from the classical formulation of the plate theory. The maximum deviation between the numerical results and the proposed methodology was $2 \%$, considering different adjustment coefficients for each opening pattern.

The adjustment coefficient equal to 0.53 (value obtained for the Anglo-Saxon typology) can be used in the proposed equation for composite beams with three typologies of openings (Anglo Saxon, Liztka and Peiner), resulting in a deviation maximum equal to $4 \%$ of the numerical results.

\section{ACKNOWLEDGMENT}

7 he authors would like to acknowledge the support provided by the Government agencies of Brazil: CAPES, CNPq, FAPEMIG and IFMG.

\section{NOTATION}

$a$

inverted "U-frame" mechanism

$d_{0} \quad$ height opening

$d_{g} \quad$ web height of the castellated section

$h_{0} \quad$ distance between the geometric centers of the flanges of the steel profile

$k \quad$ spring stiffness

$k_{g} \quad$ coefficient that takes into account effects caused by the presence of the slab in the model

$k_{\text {s }} \quad$ rotational stiffness of the composite beam

$k_{1} \quad$ cracked slab bending stiffness

$k_{2} \quad$ web rotational stiffness

$k_{2, \text { an,sol }} \quad$ analytic stiffness of the web without openings

$k_{2, \text { num,cast }}$ numeric stiffness of the castellated web

$k_{2, \text { num,sol }}$ numerical web rotational stiffness without openings

$k_{3} \quad$ shear strength stiffness

$n \quad$ number of half-waves of the buckling mode
$C_{m, d} \quad$ warping constant

$D \quad$ plate bending stiffness

E Young's modulus of the structural steel

$(\mathrm{EI})_{2}$ bending stiffness of the homogenized composite section of the slab

$F \quad$ force

$G \quad$ transverse elastic modulus of the steel

$I_{\text {afy }} \quad$ second moment of area of the compressed flange in relation to the $y$ axis

$J \quad$ St. Venant torsion constant of the profile

$L$ beam span

$M_{c r} \quad$ elastic critical moment

$\alpha_{g} \quad$ related factor to the cross-section geometry

$\beta \quad$ adjustment coefficient

$\beta_{\text {simplified }}$ simplified adjustment coefficient

$\delta \quad$ lateral displacement

$\delta_{2} \quad$ web lateral displacement

$\delta_{2, \text { ext }} \quad$ displacement of the end plate 
$t_{w} \quad$ web thickness

$s \quad$ distance between openings

$s_{e} \quad$ distance between the first and last openings

$C_{\text {dist }} \quad$ coefficient that depends on the distribution of bending moments

$\begin{array}{ll}\delta_{2, c e n} & \text { displacement of the center plate } \\ \eta_{\mathrm{b}} & \text { dimensionless parameter } \\ \nu & \text { Poisson's ratio } \\ \theta & \text { twist }\end{array}$

\section{REFERENCES}

[1] Oliveira, J.P.S. (2018). Nova Proposição para Verificação do Estado-Limite de Flambagem Lateral com Distorção de Vigas Mistas de Aço e Concreto. Ph.D. Thesis - Departamento de Engenharia de Estruturas - Programa de PósGraduação em Engenharia de Estruturas, Universidade Federal de Minas Gerais, Minas Gerais.

[2] Queiroz, G., Pimenta, R. J. and Mata, L.A.C. (2001). Elementos das Estruturas Mistas de Aço-Concreto. O Lutador, 3ed., Belo Horizonte, Minas Gerais, 332p.

[3] Associação Brasileira de Normas Técnicas. (2008). NBR 8800:2008 Projeto de Estruturas de Aço e de Estruturas Mistas de Aço e Concreto de Edifícios. Rio de Janeiro.

[4] European Committee for Standardization. (2004). EN 1994-1-1:2004. Eurocode 4: Design of Composite Steel and Concrete Structures. Part 1-1: General Rules and Rules for Buildings. Brussels.

[5] Roik, K., Hanswille, G. and Kina, J. (1990). Solution for the Lateral Torsional Buckling Problem of Composite Beams. Stahlbau, 59, p.327-332.

[6] Chen, S. (1992). Instability of Composite Beams in Hogging Bending. Ph.D. Thesis, University of Warwick, U.K.

[7] Dekker, N.W., Kemp, A.R. and Trinchero, P. (1995). Factors Influencing the Strength of Continuous Composite Beams in Negative Bending. Journal of Construction Steel Research, 34, p.161-185.

[8] Hanswille, G., Lindner, J. and Munich, D. (1998). Lateral Torsional Buckling of Composite Beams (em alemão). Stahlbau, 67, p.525-535.

[9] Calenzani, A.F.G. (2008). Proposição de Procedimento para a Determinação da Rigidez Rotacional de Vigas Mistas Contínuas e Semicontínuas com Perfis de Alma Senoidal. Ph.D. Thesis - Centro de Pós-Graduação em Engenharia de Estruturas, Universidade Federal de Minas Gerais, Belo Horizonte.

[10] Calenzani, A.F.G., Fakury, R.H., Paula, F.A., Rodrigues, F.C. and Queiroz, G. (2012). Rotational Stiffness of Continuous Composite Beams with Sinusoidal-Web Profiles for Torsional Buckling. Journal of Construction Steel Research, 79, p.22-33.

[11] Chen, S. and Wang, X. (2012). Finite Element Analysis of Distortional Lateral Buckling of Continuous Composite Beams with Transverse Web Stiffners. Advances in Structural Engineering, 15(9), pp.1067-1616.

[12] Ye, J.H. and Chen, W. (2013). Elastic Restrained Distortional Buckling of Steel-Concrete Composite Beams Based on Elastically Supported Column Method. International Journal of Structural Stability and Dynamics, 13(1), pp. 1-29.

[13] Wang, A.J. (2014). Numerically Integrated Analysis and Design of Continuous Composite Beams. Australian Journal of Structural Engineering, 15(2), pp.203-220.

[14] Guo, F., Zhou, S. and Jiang, L. (2015). Lateral Buckling Analysis of the Steel-Concrete Composite Beams in Negative Moment Region. Advances in Materials Science and Engineering, Article ID 763634, 8p.

[15] Zhou, W.B., Jiang, L.Z., Li, S.J. and Kong, F. (2015). Elastic Distortional Buckling Analysis of I-Steel Concrete Composite Beam Considering Shear Deformation. International Journal of Structural Stability and Dynamics, 16, pp. $1-22$.

[16]Zhou, W.B., Li, S.J. and Yan, W.J. (2016). Practical Formulas Towards Distortional Buckling Failure Analysis for Steel-Concrete Composite Beams. The Structural Design of Tall and Special Buildings, pp.1-18.

[17] Oliveira, J.P.S., Calenzani, A.F.G., Fakury, R.H. and Ferreira, W.G. (2016). Elastic Critical Moment of Continuous Composite Beams with a Sinusoidal-Web Profile for Lateral-Torsional Buckling. Engineering Structures, 113, pp.121132.

[18] Amaral, T.V., Oliveira, J.P.S, Calenzani, P.S.O. and Fakury, R.H. (2016). Momento Crítico Elástico Elástico à Flambagem Lateral com Distorção de Vigas Mistas de Aço e Concreto. XXXVII Iberian Latin American Congresso in Computational Methods in Engineering, Brasília-DF, Cilamce 2016.

[19] Dietrich, M.Z. (2017). Estudo da Rigidez Rotacional de Vigas Mistas de Aço e Concreto com Lajes Maciças de Concreto Armado. Dissertação de Mestrado - Departamento de Engenharia Civil - Programa de Pós-Graduação em Engenharia Civil, Universidade Federal do Espírito Santo, Vitória. 
[20] Dias, J.V.F. (2018). Determinação do Momento Crítico Elástico à Flambagem Lateral com Distorção de Vigas Mistas Contínuas e Semicontínuas. Dissertação de Mestrado - Departamento de Engenharia de Estruturas - Programa de Pós-Graduação em Engenharia de Estruturas, Universidade Federal de Minas Gerais, Belo Horizonte.

[21] Salah, W. and Gizejowski, M.A. (2008). Numerical Modelling of Composite Castellated Beams. International Conference on Composite Construction in Steel and Concrete, VI, pp. $554-565$.

[22] Salah, W. and Gizejowski, M.A. (2010). Stability and Ductility of Castellated Composite Beams Subjected to Hogging Bending. Stability and Ductility Steel Structures, Rio de Janeiro, Brazil, pp. 839-846.

[23] Salah, W. and Gizejowski, M.A. (2010). Restrained Distortional Buckling Strength of Steel-Concrete Composite Beams - A Review of Current Practice and New Developments, Modern Building Materials, Structures and Techniques, Vilnius, Lithuania, pp. 604-612.

[24] Piassi, A.D., Dias, J.V., Calenzani, A.F.G. and Menandro, F.C.C. (2018). Lateral Distortional buckling of Cellular Composite-Beams. Revista Ibracon de Estruturas e Materiais, 11(2), pp.331-356.

[25] Ansys, Inc. (2016). Release 17.0 Documentation for Ansys. Canonsburg.

[26] Fan, C.K.R. (1990). Buckling in continuous composite beams. Ph.D. Thesis, University of Warwick, U.K.

[27] Johnson, R.P. (2004). Composite Structures of Steel and Concrete: Beams, Slabs, Columns and Frames for Buildings. 3 ed. Warwick, U.K.: Blackwell, 250p.

[28] Timoshenko, S.P. and Gere, J.M. (1961). Theory of Elastic Stability. 2 ed. Nova Iorque, McGraw-Hill Book Co., $541 \mathrm{p}$.

[29] European Committee for Standardization. (1991). ENV 1994-1-1:1992. Eurocode 4: Design of Composite Steel and Concrete Structures: General Rules and Rules for Buildings. Brussels.

[30] Zaarour, W. and Redwood, R. (1996). Web Buckling in Thin-Webbed Castellated Beams; Journal of Structural Engineering, 122(8), paper 11030.

[31] Bezerra, E.M., Fakury, R.H., Castro e Silva, A.L.R., Caldas, R.B. (2010). Bending Moment Resistance for Lateral Torsional Buckling of Castellated Steel Beams, XXXIV Jornadas Sudamericanas de Ingeniería Estructural, San Juan, Argentina.

[32] Vieira, W.B. (2011). Simulação Numérica do Comportamento Estrutural de Vigas Casteladas de Aço com ênfase na Flambagem do Montante de Alma. Dissertação (mestrado) - Universidade Federal de Viçosa, Programa de PósGraduação em Engenharia Civil.

[33] European Committee for Standardization. (2002). EN 1990:2002. Eurocode: Basis of Structural Design. Brussels. 